\title{
SOSIALISASI PENINGKATAN PENGETAHUAN SISWA SMAN 1 GUNUNGSARI DAN SMKKESEHATAN AS-SYAFI'I DINUL ISLAM TERHADAP ORGANISASI DAN SISTEM PERTANDINGAN OLAHRAGA
}

\author{
Nune Wire Panji Sakti, M. Satria Mulyajaya, Adi Suriatno, Muhsan, Nurtajudin. \\ Program Studi Pendidikan Olahraga Dan Kesehatan \\ Universitas Pendidikan Mandalika Mataram
}

\begin{abstract}
Abstrak; Manusia pada hakekatnya mempunyai kesanggupan yang terbatas, baik kemampuan fisik maupun kemampuan psikis. Karena keterbatasan itulah maka manusia sering mengalami kegagalan demi kegagalan. Manusia dalam kelangsungan hidup, saling membutuhkan satu sama lain. Manusia yang ingin mencapai tujuan tertentu, maka manusia tersebut harus bekerja sama. Sehingga dengan kata lain, manusia harus bertindak dengan berorganisasi, agar tujuan tersebut dapat dicapai dengan baik. Pada tingkat kehidupan bermasyarakat yang modern, dan dengan majunya ilmu pengetahuan, daya tangkap dan kreasi manusia semakin giat, maka dari itu masyarakat mulai bertindak secara sadar di dalam melakukan tindakan-tindakan menurut tata cara organisasi.Organisasi merupakan suatu wadah yang di dalamnya terdiri dari orang orang, sarana, biaya dan tujuan yang terorganisir dengan baik untuk mencapai suatu tujuan. Demikian halnya dengan organisasi pertandingan, khususnya di dalam pertandingan olahraga, diperlukan suatu organisasi yang dapat menghimpun orang-orang untuk dapat melaksanakan suatu pertandingan olahraga dengan baik. Sehingga tujuan organisasi yang terhimpun dalam suatu kepanitiaan olahraga dapat tercapai dengan lancar dan tepat waktu. FPOK sebagai satu-satunya fakultas dilingkungan UNDIKMA Mataram yang telah menunjukkan perkembangannya yang terus maju dan inovatif dalam bidang olahraga dari sejak awal berdiri hingga sekarang, sehingga saya selaku akademisi yang memegang mata kuliah organisasi dan sistem pertandingan tahun ajaran 2019/2020. Ingin memberikan perhatian lebih dalam mengelola sistem pertandingan di lingkungan masyarakat/ sekolah (SMA, SMK dan MA). Sehingga dalam melakukan sistem pertandingan lancar, tepat sesuai peraturan, sehingga bagan tidak tumpang tindih dan serta tepat waktu dalam menyelesaikan pertandingan.
\end{abstract}

\section{PENDAHULUAN}

Manusia pada hakekatnya mempunyai kesanggupan yang terbatas, baik kemampuan fisik maupun kemampuan psikis. Karena keterbatasan itulah maka manusia sering mengalami kegagalan demi kegagalan. Manusia dalam kelangsungan hidup, saling membutuhkan satu sama lain. Manusia yang ingin mencapai tujuan tertentu, maka manusia tersebut harus bekerja sama. Sehingga dengan kata lain, manusia harus bertindak dengan berorganisasi, agar tujuan tersebut dapat dicapai dengan baik. Pada tingkat kehidupan bermasyarakat yang modern, dan dengan majunya ilmu pengetahuan, daya tangkap dan kreasi manusia semakin giat, maka dari itu masyarakat mulai bertindak secara sadar di dalam melakukan tindakan-tindakan menurut tata cara organisasi. Organisasi merupakan suatu wadah yang di dalamnya terdiri dari orang orang, sarana, biaya dan tujuan yang terorganisir dengan baik untuk mencapai suatu tujuan.Hal ini perlu dilakukan untuk dapat mengatasi pemborosan tenaga, uang, materiil, untuk mencegah sekecil mungkin kesalahan-kesalahan dan lain-lain. Tindakantindakan tersebut adalah untukpencapaian hasil yang maksimal dengan cara yang efisien dan efektif.

Demikian halnya dengan organisasi pertandingan, khususnya di dalam pertandingan olahraga, diperlukan suatu organisasi yang dapat menghimpun orangorang untuk dapat melaksanakan suatu pertandingan olahraga dengan baik. Sehingga tujuan organisasi yang terhimpun dalam suatu kepanitiaan olahraga dapat tercapai dengan lancar dan tepat waktu.Problem atau masalah 
ini saya temukan, ketika saya selalu di undang sebagai saksi dan akademisi dalam kegiatan teknikal meeting pencabutan lot bagan pertandingan di setiap sekolah yang mengadakan pertandingan baik di Lombok Barat dan Mataram Kota, banyak sekali terjadi kekeliruan yang mendasar, contohnya pada pembagian bagan pertandingan, banyak peserta mengatakan tidak adil dan posisi bye di taruh tidak sesuai dengan aturan organisasi dan sistem pertandingan yang tepat. Kepanitian dalam lingkungan sekolah, juga selalu menjadi problem, ketika berjalan di pertengahan mendekati hari " $\mathrm{H}$ " pertandingan panitia, mengalami selisih dan kadang terjadi perpecahan.

Berdasarkan problem itulah, FPOK sebagai satu-satunya fakultas dilingkungan UNDIKMA Mataram yang telah menunjukkan perkembangannya yang terus maju dan inovatif dalam bidang olahraga dari sejak awal berdiri hingga sekarang, sehingga saya selaku akademisi yang memegang mata kuliah organisasi dan sistem pertandingan tahun ajaran 2019/2020. Ingin memberikan perhatian lebih dalam mengelola sistem pertandingan di lingkungan masyarakat/ sekolah SMA, SMK dan MA. Kegiatan sosialisasi organisasi dan sistem pertandingan sangat penting di ajarkan pada sekolah yang pada zaman modern ini di tuntut untuk melakukan perkembangan dunia olahraga oleh pemerintah daerah, terlihat dari turnamenturnamen yang sering diadakan sekolahsekolah. Sehingga dalam melakukan pertandingan sekolah tersebut memiliki sistem yang benar, sehingga dalam melakukan kegiatan lancar, tepat sesuai peraturan bagan tidak tumpang tindih, adil dan tepat waktu dalam menyelesaikan pertandingan.

Target dari Program Pengabdian Masyarakat Internal "Sosialisasi Peningkatan Pengetahuan Siswa SMAN 1 Gunungsari dan SMK Kesehatan As-Syafi'i Dinul Islam Terhadap Organisasi dan Sistem Pertandingan" adalah memberikan pengetahuan awal mengenai pengertian organisasi, ciri-ciri organisasi, bentuk-bentuk organisasi, pengertian pertandingan, jenis-jenis pertandingan, bentuk-bentuk pertandingan, pengertian perlombaan, dan jenis-jenis perlombaan bagi siswa/ sekolah yang ingin mengadakan turnamen/pertandingan olahraga sehingga sistem yang di jalankan terarah, bagan pertandingan jelas dan adil serta waktu pelaksanaan dan penutupan sesuai target yang di tentukan.

Hasil yang ingin dicapai dari
kegiatan atau program Pengabdian Masyarakat Internal ini adalah sebesarbesarnya untuk kepentingan siswa/panitia di sekolah sukses dalam melakukan kegiatan dan mengenalkan kualitas akademisi FPOK UNDIKMA Mataram sehinggapara akademisi UNDIKMA Mataram khususnya Fakultas Pendidikan Olahraga dan Kesehatan, bisa menjadi pelopor pengembangan dan pembangunan dunia olahraga di NTB yaitu dalam membantu siswa dalam pelaksanaan kegiatan pertandingan dan untuk menambah pengetahuan secara luas tentang organisasi dan sistem pertandingan. Luaran tambahan yang ingin dicapai dalam pengabdian kepada masyarakat internal UNDIKMA Mataram ini berupa draft buku/ bahan ajar organisasi dan sistem pertandingan.

\section{METODE PELAKSANAAN}

\subsection{Persiapan Kegiatan}

Persiapan Kegiatan yang dilakukan terdiri dari:

1. Mekanisme sebelum pelaksanaan kegiatan Sebelum terjun ke lapangan, maka perlu dilakukan beberapa hal sebagai bentuk persiapan, antara lain:

a) Melakukan verifikasi instansi yaitu SMAN 1 Gunungsari dan SMKKesehatan As-Syafi'i Dinul Islam tempat diadakan pengabdian masyarakat ini sesuai dengaan prosedur yang berlaku di Lembaga Penelitian dan Pengabdian kepada Masyarakat di IKIP Mataram.

b) Melakukan pendataan kepada peserta program terkait dengan kegiatan yang akan dilaksanakan.

c) Mempersiapkan spanduk dan sertifikat bagi peserta dan panitia.

2. Materi sosialisasi peningkatan pengetahuan terhadap organisasi dan sistem pertandingan bagi siswa SMAN 1 Gunungsari dan SMK Kesehatan As- 
Syafi'iDinul Islam disampaikan oleh TIM Ketua yaitu Nune Wire Panji Sakti, M.Pd.

\subsection{Pelaksanaan Program}

Adapun tahapan-tahapan pelaksanaan program didesain sebagai berikut:

1. Mempersiapkan tim yang akan terjun langsung ke lapangan yaitu 1 dosen sebagai pemateri sedangkan 4 dosen lainnya terbagi atas 2 Dosen bertanggung jawab pada acara dan 2 Dosen lainnya bertanggung jawab pada peralatan dan perlengkapan.

2. Memberikan materi berupa sosialisasi peningkatan pengetahuan terhadap organisasi dan sistem pertandingan bagi siswa SMAN 1 Gunungsari dan SMK Kesehatan As-Syafi'iDinul Islam dengan durasi 90 menit, kemudian dilanjutkan dengan sesi tanya jawab antara peserta dan pemateri.

3.3. Rancangan Pelaksanaan Pengabdian Masyarakat

Tabel 3.1. Rancangan Pelaksanaan

Pengabdian

\begin{tabular}{|c|c|c|c|c|}
\hline $\mathrm{N}_{0}$ & Rancangan Keggiatan & Waktu & Pelaksanaan & Pemateri \\
\hline & $\begin{array}{l}\text { Penyampaian materi tentang } \\
\text { pentingnyya pengetahuan } \\
\text { terhadap organisasi dan sistem } \\
\text { pertandingan } \\
\text { a) Sejarah dan pengertian } \\
\text { organisasi, } \\
\text { b) Bentuk organisasi, } \\
\text { c) Manffaat organisasi, } \\
\text { d) Manajemen organisasi, } \\
\text { e) jenis-jenis pertandingan, } \\
\text { f) Struktur organisasi dan tugas } \\
\text { gerta tanggung jawab panitia, } \\
\text { g) pengertian system kompetisi } \\
\text { h) system kompetisi penuh, } \\
\text { setengah kompetisi } \\
\text { i) jenis-jenis perlombaan } \\
\text { j) pengurutan peringkat } \\
\text { k) Laporan akhir dan laporan } \\
\text { keuangan }\end{array}$ & $\begin{array}{c}10.00-11.30 \\
\& \\
15.00-17.00\end{array}$ & $\begin{array}{l}\text { Team: } \\
\text { Nune Wire Panjil } \\
\text { Sakti, M. Pd } \\
\text { Muhammad Satria } \\
\text { Mulyajaya, M.Pd } \\
\text { Adi Suriatno, M.Psi } \\
\text { Muhsan, S.Pd., M.Or } \\
\text { Nurtajudin, M.Pd }\end{array}$ & $\begin{array}{l}\text { Nune Wire } \\
\text { Panji Sakti, } \\
\text { M.Pd }\end{array}$ \\
\hline
\end{tabular}

\subsection{Jadwal Kegiatan Program}

Kegiatan pengabdian masyarakat ini dilaksanakan pada bulan Agustus tahun 2019 di SMK Kesehatan As-Syafi'i Dinul Islam dan SMAN 1 Gunungsari dengan peserta 50 orang, yang masing-masing siswa SMAN 1 Gunungsari berjumlah 25 orang siswa dan SMK Kesehatan AsSyafi'iDinul Islam berjumlah 25 orang siswa yang terlibat di OSIS dan khususnya kegiatan pertandingan, pada saat mengadakan kejuaraan dan class meeting di sekolah.

\section{HASIL KEGIATAN PENGABDIAN Gambaran Umum Lokasi Kegiatan Masyarakat}

SMK Kesehatan As-Syafi'i Dinul Islam dan SMAN 1 Gunungsari merupakan salah satu sekolah swasta dan negeri yang berada di Kecamatan Gunungsari Kabupaten Lombok Barat Provinsi Nusa Tenggara Barat. Sejak berdiri sampai sekarang ini sekolah tersebut yang di komandoi oleh OSIS mereka masing-masing sangat ingin menyelenggarakan pertandingan atau turnamen Futsal. Pada sekolah kejuruan dan menengah atas inilah tim pengabdian UNDIKMA melakukan kegiatan pengabdian masyarakat dengan tema "Sosialisasi Peningkatan Pengetahuan Siswa SMAN 1 Gunungsari dan SMK Kesehatan As-Syafi'i Dinul Islam Terhadap Organisasi dan Sistem Pertandingan". Pemilihan lokasi tersebut berdasarkan dari hasil observasi awal yang menunjukkan adanya siswa yang tergabung dalam OSIS sekolah tersebut yang ingin menyelenggarakan pertandingan futsal sebagai agenda tahunan yang akan di selenggarakan di ULTAH sekolah.

\section{Gambaran Umum Peserta Pengabdian Masyarakat}

Kegiatan pengabdian ini dihadiri oleh total 50 peserta yaitu anggota OSIS SMAN 1 Gunungsari dan SMK Kesehatan As-Syafi'i Dinul Islam. Anggota OSIS yang khususnya dalam bidang keolahragaan, yang tentunya sering mengadakan kejuaraan dalam skim class meeting di sekolahnya masing-masing.

\section{Pelaksanaan Pengabdian Masyarakat}

Sebagaimana yang telah diuraikan pada sub-sub tema sebelumnya, bahwa kegiatan pengabdian masyarakat ini terlahir dari hasil observasi awal pada anggota OSIS tersebut yang setiap melakukan kegiatan classmeeting menjelang berakhirnya UAS di sekolah mereka masing-masing dan keinginan besar mereka yang ingin membuat agenda 
tahunan yaitu membuat pertandingan atau turnamen futsal skala kabupaten maupun Provinsi nantinya. Karena perlu di ketahui sekolah kecamatan Gunungsari tersebut belum pernah menyelenggaran turnamen futsal skala kabupaten maupun provinsi sama sekali.

Keinginan atau mimpi besar anggota OSIS tersebutlah makaFPOK UNDIKMA hadir memberikan solusi agar nantinya bukan turnamen futsal yang mereka bisa selenggarakan dengan skala kabupaten maupun provinsi nantinya. Karena dengan adanya turnamen besar skala kabupaten maupun provinsilah sekolah mereka bisa dikenal di kalangan masyarakat. Hal tersebut sangat penting dilakukan oleh sekolah secara mandiri, dimana dengan cara itu dapat mendidik siswa dalam segala hal, yang pertama siswa dapat mengembangkan potensinya dalam menjadi EO pertandingan, ke dua siswa dapat di ajarkan mandiri dalam berusaha untuk bisa sukses dalam tujuannya, ke tiga siswa bisa bersosialisasi dan memiliki perencanaan dengan baik, dan selanjutnya bisa di ajarkan cara bekerjasama dalam berorganisasi dengan baik sehingga bisa mencapai tujuannya dengan sukses, dan yang paling penting siswa tersebut bisa membuat laporan akhir serta laporan keuangan untuk pertanggung jawaban dalam melaksanakan berbagai macam kegiatan turnamen.

Selanjutnya, kegiatan pengabdian masyarakat ini dilaksanakan pada hari Jum'at tanggal 5 Agustus 2019 di SMAN 1 Gunungsari dan SMK Kesehatan As-Syafi'i Dinul Islamdengan 1 orang pemateri. Kegiatan dilakukan dari jam 10.00 pagi sampai jam 11,30 siang, lokasi di SMAN 1 Gunungsaridan di SMK Kesehatan As-Syafi'i Dinul Islam dilakukan dari jam 15.00 siang sampai jam 17,00 sore.Kegiatan ini dilakukan dengan metode penyampaian materi dan tanya jawab.

Tahapan kegiatan akhir, perwakilan inti dalam bidang keolahragaan di OSIS sekolah mereka masing-masinglangsung diberikan pengalaman mengadakan pertandingan oleh FPOK IKIP Mataram yang sekarang beralih nama menjadi UNDIKMA dengan tema kegiatan pertandingan Dekan Futsal FPOK IKIP Mataram tahun 2019 yang di lakukan persiapan dari bulan Agustus sampai pelaksanaan turnamen yaitu 20 Oktober hingga 26 Oktober 2019 bertempat di lapangan futsal Gelanggang Pemuda Olahraga Mataram prov. NTB. Hasil menunjukkan semua peserta merasakan mendapatkan pengetahuan baru yang berhubungan dengan Organisasi dan sistem pertandingan, baik pengalaman administrasi hingga pengalaman lapangannya dan mereka mengharapkan bisa melakukan agenda tersebut pada saat ULTAH sekolah mereka masing-masing.

\section{KESIMPULAN KEGIATAN}

Sistem pertandingan lancar, tepat sesuai peraturan, sehingga bagan tidak tumpang tindih dan serta tepat waktu dalam menyelesaikan pertandingan.

\section{DAFTAR PUSTAKA}

Aip Sarifudin, Organisasi dan Tatalaksana Penyelenggaraan Pertandingan Olahraga, untuk SPG, SGO, SGPLB, Departemen Pendidikan dan Kebudayaan, Jakarta, 1981.

Edward. F, etal, The Organization and Administration of Physical Education, New York, Appleton-Century-Crofts, Inc., 1978.

Husdarta JS. Pendidikan Olahraga dan Kesehatan, Bahan Perkuliahan MKDU, Olahraga dan Kesehatan IKIP Bandung, 1988.

KONI Pusat, (2017), Susunan Pengurus KONI Pusat, KORWIL, KONI Induk Organisasi Cabang Olahraga dan Badan Fungsional. 